\title{
Experimental lamellar keratoplasty in rabbits using microfibrilar cellulose membrane. Clinical, morphological and immunohistochemical findings
}

\author{
Ceratoplastia lamelar experimental em coelhos usando membrana microfibrilar de celulose. \\ Achados clínicos, morfológicos e imunoistoquímicos
}

\author{
Luciana Riacciardi Macedo ${ }^{I}$ Alexandre Pinto Ribeiro ${ }^{I I}$ Luciano Fernandes da Conceição ${ }^{I I}$ \\ Paula Diniz Galera' ${ }^{\text {III }}$ José Luiz Laus ${ }^{\text {IV }}$
}

\begin{abstract}
The clinical, histopathological and immunohistochemical features of the cornea were investigated in adult male New Zealand rabbits submitted to lamellar keratoplasty with microfibrillar cellulose membrane. Thirty animals were divided into five groups $(n=6)$ and evaluated up to 60 days after surgery. Clinical examination revealed moderate manifestations of edema, blepharospasm and photophobia on the second day, which became mild or disappeared after the seventh day. This period was characterized clinically by repair of the corneal defect. Histopathological analysis showed the presence of a thin layer of squamous cells covering the damaged area as early as $7^{\text {th }}$ day, accompanied by a mild infiltrate of polymorphonuclear cells. Blood vessels were observed in the epithelium after the $15^{\text {th }}$ day, which had regressed by day 48 . Ki67 antibody labeling showed an increase of proliferating cells in the epithelium by the $15^{\text {th }}$ day and in the stroma by day 30. Remodeling and epithelial adhesion were observed during this period. Microfibrillar cellulose membrane (Bionext ${ }^{\circledR}$ ) used for lamellar keratoplasty was found to yield good results considering the good integration of the implant.
\end{abstract}

Key words: corneal repair, surgery, cell proliferation, Ki67.

\section{RESUMO}

Avaliaram-se aspectos clínicos, histopatógicos e imunoistoquímicos da córnes de coelhos da raça Nova Zelândia adultos e machos em ceratoplastias lamelares com membrana de celulose microfibrilar. Trinta animais distribuídos em cinco grupos $(n=6)$ foram estudados por até 60 dias de pósoperatório. A avaliação clínica revelou manifestações moderadas de edema, blefaroespasmo e fotofobia ao segundo dia, evoluindo para formas discretas ou ausentes a partir do sétimo dia, período em que se observou, clinicamente, reparo do defeito corneal. A histopatologia revelou uma fina camada de células escamosas, recobrindo a área lesada já aos sete dias, com discreto infiltrado de células polimorfonucleares. Observaram-se vasos no epitélio a partir do 15임 com regressão ao 48 dia. A marcação com o anticorpo Ki67 mostrou aumento de células em proliferação aos 15 dias no epitélio e aos 30 dias no estroma. Nesse período, ocorreram remodelamento e adesão epitealial. Considerando a boa integração do implante, admite-se a membrana de celulose como um bom material a ser utilizado em ceratoplastia lamellar.

Palavras-chave: reparação corneal, cirurgia, proliferação celular, Ki67.

\section{INTRODUCTION}

Ulcerative keratitis resulting from infectious or non-infectious destructive processes is a frequent and important condition in ophthalmology because of its high morbidity (BRITO et al., 2006). Palpebral, ciliary and lacrimal anomalies as well as traumas are the main factors associated with the pathogenesis of ulcerative keratitis (GELATT \& GELATT 2001; GALERA et al., 2009).

Various methods are available for the repair of damaged corneal tissue, with treatment being either clinical or surgical. Clinically, topical agents that inhibits

IMédica veterinária autônoma. Petoftalmovet, São Paulo, SP, Brasil.

IIPrograma de Pós-graduação em Cirurgia Veterinária, Faculdade de Ciências Agrárias e Veterinárias (FCAV), Universidade Estadual Paulista (UNESP), Jaboticabal, SP, Brasil.

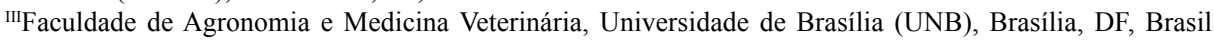

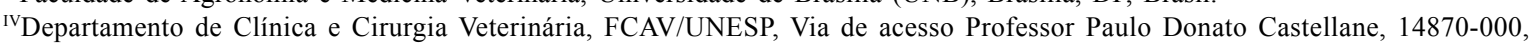
Jaboticabal, SP, Brasil. E-mail: jllaus@fcav.unesp.br. Autor para correspondência. 
collagenolitic enzymes, such as autologous and xenologous serum, EDTA, and acetylcisteine, as well as other molecules that modulate corneal wound healing, such as epidermal growth factor, insulin growth factor, and nerve growth factor have been investigated (BENTLEY \& MURPHY, 2004). The surgical treatments most widely used in veterinary medicine include tarsorrhaphy, third eyelid flap, pedicle and non-pedicle conjunctival grafts, and corneoscleral transposition (GELATT \& GELATT, 2001; GALERA et al., 2009). However, new reparative materials had been tested in the field of veterinary ophthalmology; and include xenologous pericardium, homologous peritoneum, xenologous renal capsule, sardine scale, xenologous and homologous amniotic membrane, homologous vaginal membrane, porcine small intestine submucosa (BUSSIERES et al., 2004; SAMPAIO et al., 2006; GALERA et al., 2009). Within this context, microfibrillar cellulose membranes have been used for the temporary replacement of skin in burns, abrasions, ulcers, or cases of tissue loss (REBELLO et al. 1987; PIPPI \& SAMPAIO, 1990; DALECK \& BECHARA 1991; SCHOENAU et al., 1993). These membranes consist of polysaccharides formed by thousands of molecules of cellobiose synthesized by the bacterium Acetobacter xylinum. PIPPI \& SAMPAIO (1990) used this membrane in an experimental study on the repair of lamellar corneal lesions in rabbits. SCHOENAU et al. (1993) successfully repaired corneal defects using suture and a cellulose membrane; the authors reported faster regeneration of the corneal epithelium and reduced infiltration by polymorphonuclear cells. However, it is known that no recent studies have been carried out regarding the impact of such material in corneal cell proliferation by immunohistochemistry. In this context, the cell marker Ki67 has been widely used in the field of the investigative ophthalmology (WILSON et al., 2001; BALDWIN \& MARSHALL, 2002; CRESTA\& ALVES, 2007; PAULY et al., 2009).

Therefore, the present study aimed to evaluate clinical, morphological and immunohistochemical events that occur in the cornea of rabbits submitted to lamellar keratoplasty with microfibrillar cellulose membrane implant.

\section{MATERIAL AND METHODS}

Thirty healthy male New Zealand rabbits with a mean weight of $3.0 \mathrm{~kg}$ and a mean age of 120 days were studied. Before inclusion in the study, the animals underwent a full ophthalmic examination, which consisted of Schirmer tear test, dazzle and pupillary light reflexes, slit lamp examination, tonometry, indirect ophthalmoscopy, and fluorescein dying of the cornea. Healthy animals were selected, identified and maintained in appropriate cages in a ventilated, clean, dry and protected environment. Commercial chow and potable water were available ad libitum.

Cellulose synthesized by Acetobacter xylinum is used as raw material for fabrication of the membrane ${ }^{a}$. The product is commercially available in fragments measuring $1.0 \times 1.5 \times 0.2 \mathrm{~mm}$. For keratoplasty, $0.2 \mathrm{mg} \mathrm{kg}^{-1}$ rabbits were sedated with subcutaneous acepromazine $^{\mathrm{b}}$, and anesthesia was induced with the combination of intramuscular injection of $30 \mathrm{mg} \mathrm{kg}^{-1}$ body weight ketamine ${ }^{\mathrm{c}}$ and $5 \mathrm{mg} \mathrm{kg}^{-1}$ xylazine hydrochlorid $^{\mathrm{d}}$, and was maintained by inhalation of isoflurane ${ }^{e}$. The surgical interventions were performed under a surgical microscope at $16 \mathrm{X}$ magnification ${ }^{\mathrm{f}}$. After routine antisepsis and protection of the surgical field, and blepharostasis, a lamellar button comprising the epithelium and half the thickness of the stroma was then created with a $5 \mathrm{~mm}$ diameter trephine $\mathrm{g}^{\mathrm{g}}$ in the axial region, and corneal lamella was excised with an angled slit blade ${ }^{\mathrm{h}}$. After the cornea was dried with a sterile swab, the membrane previously kept in sterile $0.9 \%$ saline for $1 \mathrm{~min}$ was attached to the recipient bed with eight simple interrupted equidistant (average of $1 \mathrm{~mm}$ ) sutures using 9-0 non-absorbable monofilament ${ }^{i}$. After surgery, topical $0.3 \%$ tobramycin ${ }^{j}$ was instilled at intervals of 6 hours for 7 consecutive days and $0.02 \mathrm{mg}$ $\mathrm{kg}^{-1}$ buprenorphine ${ }^{1}$ was administered subcutaneously at 12-hour intervals for 5 consecutive days.

Clinical examination was started on the first postoperative day and was continued at regular intervals of 24 hours for 60 consecutive days. Blepharospasm, corneal edema, neovascularization, photophobia and ocular discharge were characterized subjectively using a scoring system as absent (0), mild (1), moderate (2), and severe (3).

Histopathological events were evaluated at $1,7,15,30$ and 60 days after surgery. Using the same anesthetic protocol as adopted for keratoplasty, six rabbits were euthanatized after each period and their eyes were enucleated from the orbit, cleaned with $0.9 \%$ saline and immersed in $10 \%$ buffered formalin. Next, the corneas were cut sagittally to the graft area following parallel meridians and immersed in increasing concentrations ( 70 to $100 \%$ ) of ethyl alcohol. The specimens were embedded in paraffin, cut into $3 \mu \mathrm{m}$ thick sections with a microtome, and the sections were stained wit hematoxylin-eosin.

For immunohistochemistry the specimens were deparaffinized and antigen retrieval was performed by boiling the specimens in EDTA, $\mathrm{pH} 8.0$, for 30min in a pressure cooker at $95^{\circ} \mathrm{C}$. The specimens were then 
washed for $10 \mathrm{~min}$ with oxygenated water, followed by washing under running water. Next, the specimens were washed in Tris- $\mathrm{HCl}$ buffer and incubated with the primary Ki67 antibody ${ }^{\mathrm{m}}$ diluted 1:50 at $8^{\circ} \mathrm{C}$ for 12 hours. The specimens were again washed in Tris- $\mathrm{HCl}$ buffer and incubated with the secondary antibody for $20 \mathrm{~min}$, followed by washing in Tris-HCl buffer. Each slide was incubated with diaminobenzidine solution dissolved in PBS and hydrogen peroxide for $15 \mathrm{~min}$. The Ki67 antibody is used for the evaluation of mitosis. Ki67immunostained cells were counted for the quantification of cell proliferation. Ten microscopic fields in the central area of the graft were standardized, with each field corresponding to an area of approximately $40 \mathrm{X}$ of magnification. The epithelium and stroma were evaluated and slides were analyzed in a double-blind fashion and the images were captured and photographed irrespective of staining intensity.

\section{RESULTS}

Mild blepharospasm (1) was observed on the first day in all animals. Blepharospasm was moderate (2) between day 4 and day 14, and was no longer observed (0) thereafter until day 60. Similar findings were observed for photophobia. Edema was mild (1) from day 2 to day 18 in all animals, and was no longer observed ( 0 ) thereafter. Moderate (2) ocular discharge was observed from day 2 to day 16 , followed by mild (1) discharge between days 17 and 48 and the absence of any discharge at the end of the observation period. Conjunctival hyperemia was intense (3) after day 2 (Figure 1A), becoming moderate (2) by day 28 , and was no longer observed (0) by day 60 (Figure 1B). Mild neovascularization (1) was observed between day 15 and day 48, and only ghost vessels could be noted at the completion of the study (Figure 1B). Moderate corneal pigmentation (1) was observed after day 30 in only two animals and had disappeared by day 48 .

Regarding to histopathological findings, discrete mild differences in cellular and vascular components and in corneal tissue organization were observed between the periods studied. No epithelium was detected on the first day and inflammation was characterized by the presence of subepithelial neutrophils, eosinophils and plasma cells close to the basement membrane. Infiltrate decreased after day 7 , with the observation of fibroblast proliferation and collagen disorganization. After 15 days, a continuous stratified epithelium was observed, and was intermingled by macrophages, keratocytes; lymphocytes and polymorphonuclear were rare. Vessel proliferation was noticed next to areas of hyperplastic epithelium and basal cells, which presented marked hypertrophy (Figure 2A). After 30 days, fibroblast remodeling was observed beneath the corneal epithelium and disorganized fibers were still present. Few mononuclear cells, organized collagen fibers, and thin intact corneal epithelium predominated at 60 days (Figure 2B).

The number of Ki67-immunostained cells varied with the stage of corneal regeneration,

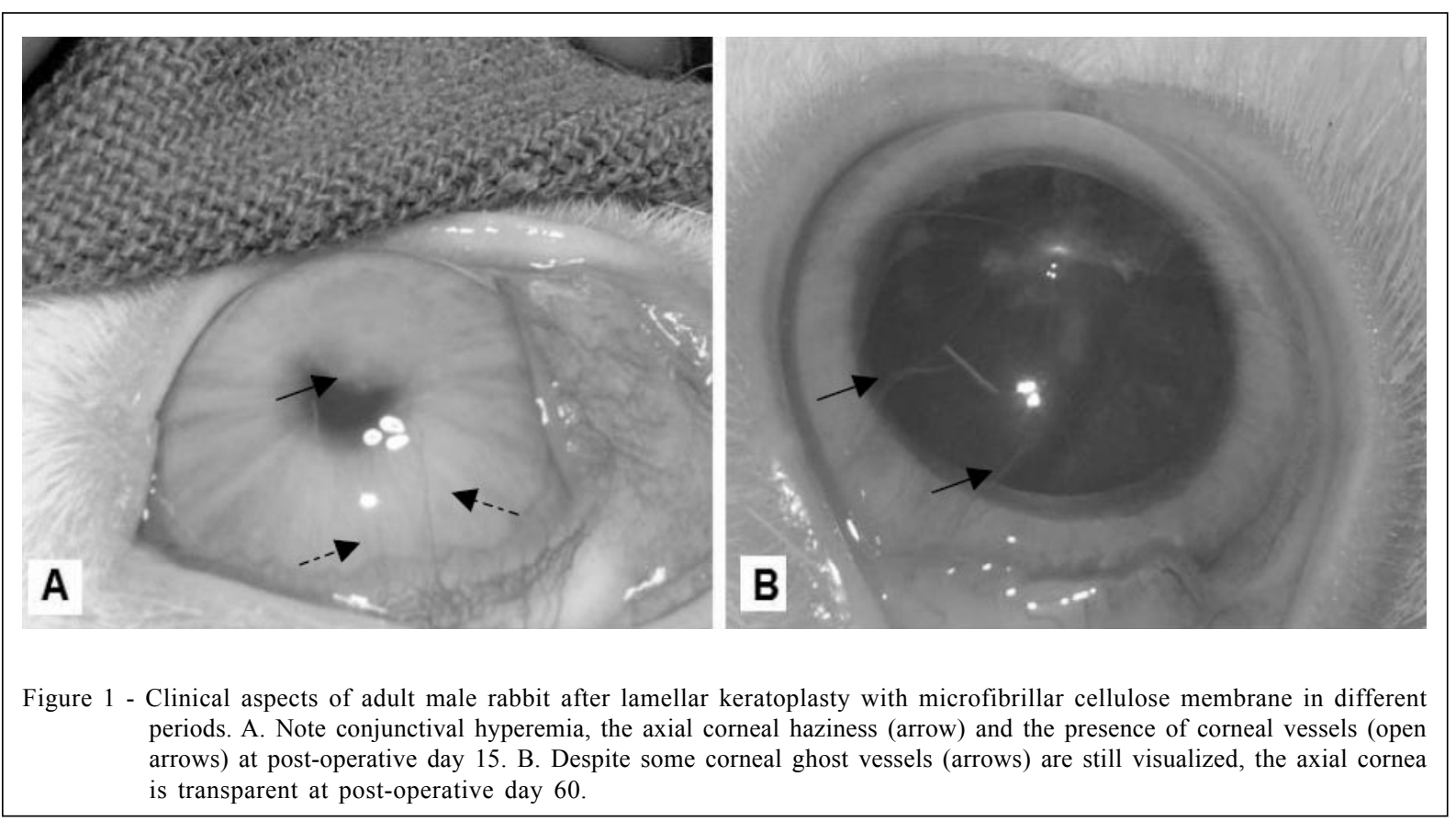

Ciência Rural, v.40, n.2, fev, 2010. 

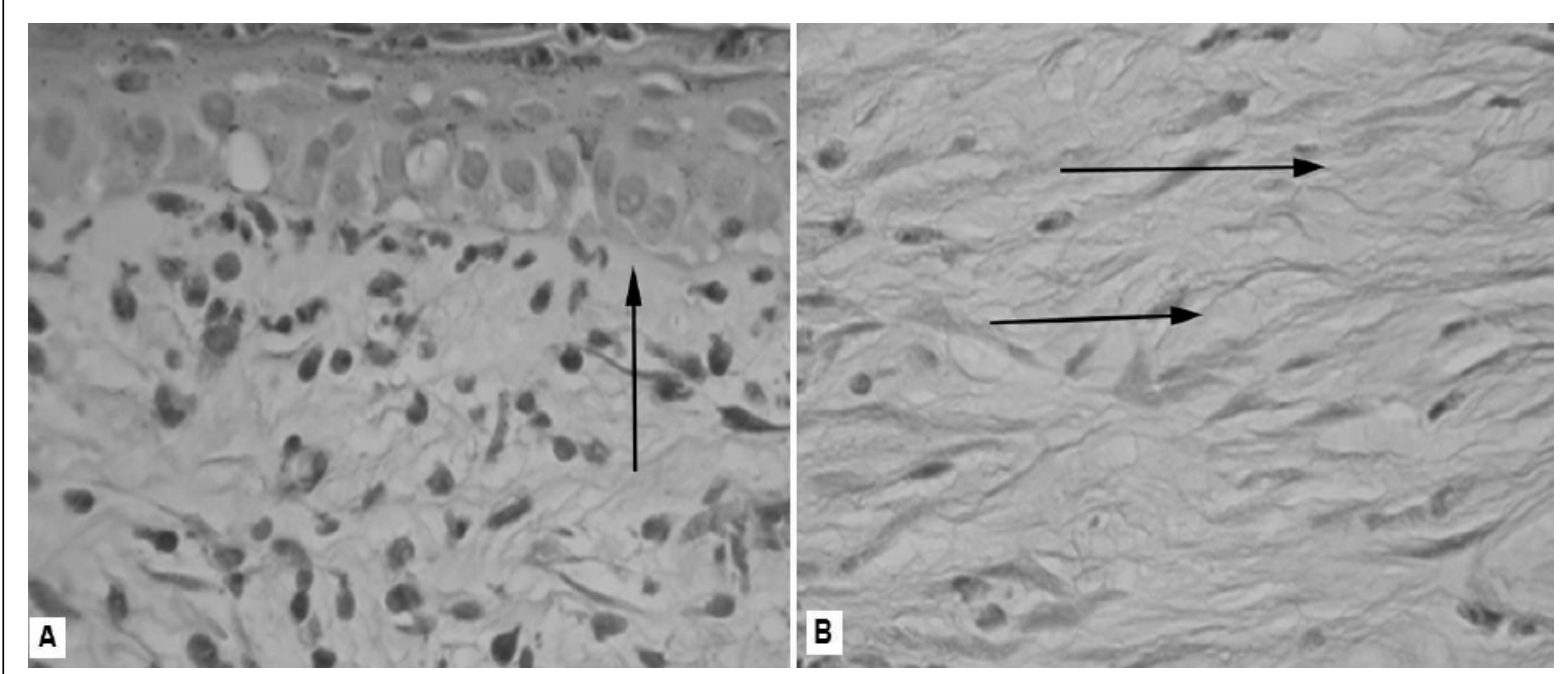

Figure 2 - A. Photomicrograph of the cornea of an adult male rabbit after lamellar keratoplasty with microfibrillar cellulose membrane in different periods. A. Note the presence of hyperplasia and marked hypertrophy of basal cells, 15 days after surgery (arrow). 40x, HE. B. At day 60, collagen fibers are arranged in a parallel and organized manner (arrows). 100x, HE.

particularly in the epithelium. The highest mitotic index per field was observed on postoperative day 15 in the epithelium $(0.71 \pm 0.65)$ and on day 30 in the corneal stroma (1.06 \pm 1.78$)$, with the difference between the epithelium and stroma being significant $(P=0.04)$. Comparison between the periods studied showed a significant difference in mean mitotic index in the epithelium (between day 1 and day $15, \mathrm{P}=0.042$ ) (Figure $3 \mathrm{~A}$ ). and stroma (between day 1 and day 30, $\mathrm{P}=0.049$ ) (Figure 3B).

\section{DISCUSSION}

Surgical treatment of corneal disorders is the main therapeutic modality in medical and veterinary ophthalmology (GELATT \& GELATT, 2001; GALERA et al., 2009). Rupture of the corneal epithelium and exposure of the stroma leads to an increased recruitment of metalloproteinases produced by bacteria and by the damaged tissue, triggering rapid stromal degradation. In veterinary ophthalmology, corneal transplants are less frequently performed due to the difficulty in maintaining viable corneas in eye banks (GALERA et al., 2009), a fact that has resulted in the frequent investigation of new materials. REBELLO et al. (1987) were the first ones to use microfibrillar cellulose membrane for human skin grafts. In canine eyes, microfibrillar cellulose membranes were used for the first time in 1990 for the repair of ulcerated corneas and bulbar conjunctival defects (PIPPI \& SAMPAIO, 1990).
Photophobia and blepharospasm observed in the present study after the third postoperative day were probably due to surgical trauma, sutures, and exposure of the nociceptive innervation (GELATT \& GELATT, 2001; GALERA et al., 2009). Corneal edema manifested as an opacity surrounding the graft area. Edema was expected and was the result of surgical trauma accompanied by breakdown of the integrity of the epithelial layer(GELATT \& GELATT, 2001; GALERA et al., 2009). Edema disappeared because of migration of the corneal epithelium over the defect created, an event confirmed by histopathology.

Histopathological analysis revealed corneal reepithelization accompanied by basal cell mitosis. The cornea possesses intrinsic mechanisms involved in repairing and wounding of its architecture. The proximity of the cornea to the conjunctiva provides the trophic and defense support necessary for its regeneration (GALERA et al., 2009). When modulated, corneal vascularization is expected and desired for the wound healing process (GALERA et al., 2009). In the present study, corneas receiving the cellulose membrane started to form new vessels after day 15 , similar to the findings of other investigators using different materials (GALERA et al., 2009). Although direct comparison of the present data with those observed in other experiments is not very reliable, the cellulose membrane was found to induce less marked corneal neovascularization, in comparison to corneas of rabbits in which keratoplasties were performed with bovine amniotic membrane (SAMPAIO et al., 2006). 


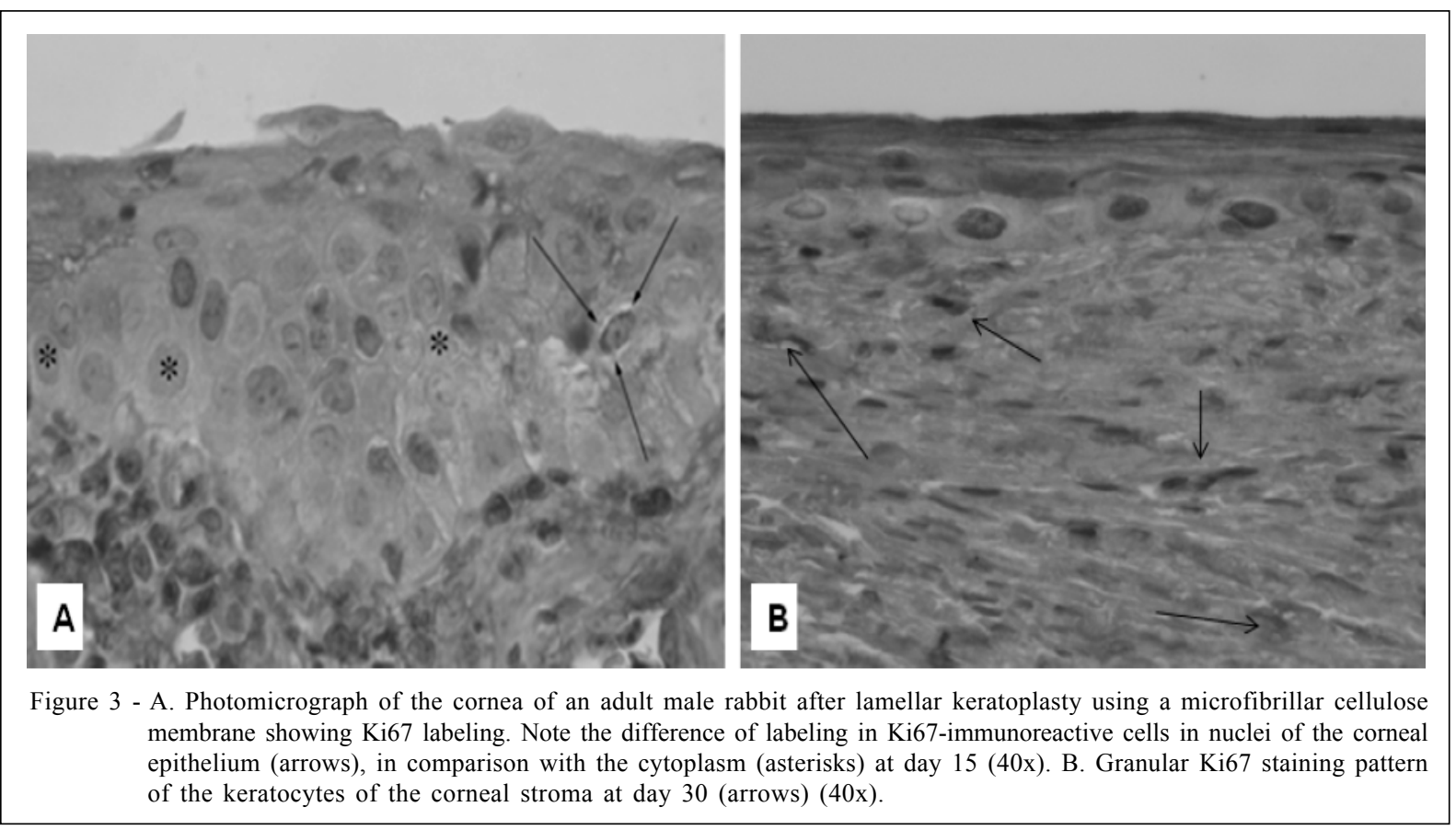

A predominance of polymorphonuclear cells was observed in the present study. Increased vascular permeability and cell recruitment were noted by day 7 . There was a thin layer of squamous epithelial cells covering the corneal defect. These findings agree with those reported by other investigators using different materials (SAMPAIO et al., 2006; GALERA et al., 2009).

Integration of the cellulose membrane into the cornea was observed between the seventh and tenth postoperative day, similar to the findings obtained when an amniotic membrane was used for the repair of corneas after n-heptanol damage (SAMPAIO et al., 2006). According to the literature, the time the graft needs to remain on the keratectomy area varies according to the origin of the material and characteristics of the ocular surface, and its absorption varies according to the intensity of local inflammation (SAMPAIO et al., 2006). Prevention of rejection of the implanted material and good integration are facilitated by rigorous pre-, trans- and postoperative care (SAMPAIO et al., 2006).

Different methods are available for the evaluation of cell proliferation during inflammation (WILSON et al., 2001; BALDWIN \& MARSHALL, 2002; PAULY et al., 2009). Ki67 has been shown to be a useful marker for the investigation of cell proliferation in corneal epithelium and stroma of rabbits (CRESTA \& ALVES, 2007; PAULY et al., 2009). During corneal wound healing, the epithelium migrates, proliferates and reestablishes its adhesions. Ki67 is an antigen expressed during the cell cycle. Except for the initial G1 and G0 phase, its expression increases during the last half of the $S$ phase, reaching its peak during the $G 2$ phase of mitosis. The half-life of Ki67 is short (less than one hour after mitosis). Thus, the use of Ki67 antibody guarantees that only cells that have completed the cell cycle are stained (CRESTA\& ALVES, 2007; PAULY et al., 2009), a fact observed in the present study.

Differences in mean Ki67 labeling were observed in the epithelium after 15 days and in the stroma after 30 days compared to the other periods. In the present study, stromal reorganization and a higher degree of proliferation of Ki67-immunostained cells were observed after 30 days when remodeling of stromal collagen was noted. These findings support the continued presence of intrinsic mechanisms that exacerbate even after resolution of the corneal defect (CRESTA\& ALVES, 2007; PAULY et al., 2009).

It is assumed that growth factors play a critical role in corneal healing (BENTLEY \& MURPHY, 2004). To date, it has been proved that amniotic membrane and porcine small intestine submucosa expresses several growth factors which decrease the activity of matrix metalloproteinases, facilitates the reinforcement of the adhesion of basal epithelial cell, promote epithelial differentiation, and prevent apoptosis (BUSSIERES et al., 2004; SAMPAIO et al., 2006; GALERA et al., 2009). Despite the god results and cosmetics achieved in our study, further 
investigation is necessary to determine if some of the growth factors aforementioned are expressed by microfibrilar cellulose membrane.

\section{CONCLUSION}

Under the present experimental conditions, the microfibrillar cellulose membrane used for lamellar keratoplasty was found to yield good results considering the good integration of the implant.

\section{ETHICS COMMITTEE ON ANIMAL EXPERIMENTATION}

The study was conducted according to the international guidelines of the Association for Research in Vision and Ophthalmology and was approved by the Animal Welfare Ethics Committee (protocol 008771-07).

\section{SOURCES OFACQUISITION}

a - Bionext ${ }^{\mathbb{R}}$ - Produtos biotecnológicos Ltda.

b - Acepran ${ }^{\circledR}$ - Univet, Brasil

c - Ketamine ${ }^{\circledR}$ - Syntec, Brasil

d - Rompum ${ }^{\circledR}$ - Bayer, Brasil

e - Isofluorine ${ }^{\circledR}$ - Cristália, Brasil

f - MC - M900® Surgical microscope - DF Vasconcelos

g - Corneal trephine instrument with depth setting, Jomubi ${ }^{\circledR}$ Equipamentos de Precisão, Brasil

h - CM Phaco Slit Blade Angled $5.2 \mathrm{~mm}$; 45, Eagle, USA

i - Monoylon 9.0, Johnson \& Johnson, SP, Brasil

j - Tobramycina $0.3 \%$, solução oftálmica $5 \mathrm{ml}$, Alcon ${ }^{\circledR}$, Brasil

1 - Tengesic ${ }^{\circledR}$, Cristália, Brasil

m - Cytomation monoclonal mouse anti-human Ki67 antibody, clone MIB-1, Dako, USA

\section{REFERENCES}

BALDWIN, H.C.; MARSHALL J. Growth factors in corneal wound healing following refractive surgery: a review. Acta Ophthalmologica Scandinavica, v.80, n.3, p.238-247, 2002. Available from: http://www3.interscience.wiley.com/cgibin/fulltext/118927387/PDFSTART. Accessed: aug. 10, 2009 doi: $10.1034 /$ j.1600-0420.2002.800303.x

BENTLEY, E.; MURPHY, C.J. Topical therapeutic agents that modulate corneal wound healing. Veterinary Clinics of North America: Small Animal Practice, v.34, n.3, p.623638,2004

BUSSIERES M. et al. The use of porcine small intestinal submucosa for the repair of full-thickness corneal defects in dogs, cats and horses. Veterinary Ophthalmology, v.7, n.5, p.352-359, 2004. Available from: http:// www3.interscience.wiley.com/cgi-bin/fulltext/118811906/ PDFSTART. Accessed: aug. 10, 2009. doi: 10.1111/j.14635224.2004.04055.x

F.L.C. BRITO et al. Amastigota forms resembling Leishmania sp. on corneal ulceration in a dog: case report. Arquivos
Brasileiros de Medicina Veterinária e Zootecnia, v.59, n.1, p.81-84, 2007. Available from: http://www.scielo.br/pdf/ abmvz/v59n1/14.pdf. Accessed: aug. 10, 2009. doi: 10.1590/ S0102-09352007000100014

CRESTA, F.B.; ALVES, M.R. Avaliação da cinética do epitélio corneano com marcadores de proliferação celular. Arquivo Brasileiro de Oftalmologia, v.70, n.6, p.953-960, 2007. Available from: http://www.scielo.br/pdf/abo/v70n6/ a13v70n6.pdf. Accessed: aug. 10, 2009. doi: 10.1590/S000427492007000600013

DALECK, C.R.; BECHARA, G.H. Curativo biológico Biofill no tratamento de feridas cutâneas em cães, resultados parciais. Boletim de Ciência Veterinária, v.5, n.1, p.2633, 1991 .

GALERA, P.D. et al. Afecções da túnica fibrosa. In: LAUS J.L. Oftalmologia clínica e cirúrgica em cães e em gatos, São Paulo: Roca, 2009. p.69-96.

GELATT, K.N.; GELATT, J.P. Surgery of nasolacrimal apparatus and tear systems. In: Small animal ophthalmic surgery: practical techniques for the veterinarian. Oxford: Butterworth \& Heinemann, 2001. p. 125-141

PAULY, A. et al. Multiple endpoint analysis of the $3 \mathrm{~d}$ reconstituted corneal epithelium after treatment with benzalkonium chloride: early detection of toxic damage. Investigative Ophthalmology and Visual Science, v.50, n.4, p.1644-1652, 2009. Available from: http://www.iovs.org/ cgi/content/abstract/50/4/1644. Accessed: aug. 10, 2009. doi: 10.1167/iovs.08-2992.

PIPPI, N.L; SAMPAIO, A.J.S.A. Estudos preliminares sobre o comportamento do Biofill na ceratoplastia lamelar em coelhos. Revista do Centro de Ciências Rurais, v.20, n.3-4, p.297302, 1990

REBELLO, C. et al. Bio-fill, um novo substituto de pele: nossa experiência. Revista Brasileira de Cirurgia, v.77, n.6, p.407-414, 1987

SAMPAIO, R.L. et al. Aspectos clínicos e imunopatológicos da ceratoplastia com membrana amniótica xenógena a fresco e conservada em glicerina: estudo experimental em coelhos. Arquivos Brasileiros de Medicina Veterinária e Zootecnia, v.58, n.6, p.1077-1085, 2006. Available from: http://www.scielo.br/pdf/abmvz/v58n6/16.pdf. Accessed: aug. 10, 2009. doi: 10.1590/S0102-09352006000600016.

SCHOENAU, L.S.F. et. al. Avaliação clínica preliminar do fechamento comparativo de incisões corneanas com sutura e Biofill® película celulósica. Ciência Rural, v.23, n.2, p.173$177,1993$.

WILSON, S.E. et al. The corneal wound healing response: cytokine-mediated interaction of the epithelium, stroma, and inflammatory cells. Progress in Retina and Eye Research, v.20, n.5, p.625-637, 2001. Available from: http:// www.sciencedirect.com/science? /sdarticle.pdf. Accessed: aug. 10, 2009. 